\title{
Response of streamflow to projected climate change scenarios in an eastern Himalayan catchment of India
}

\author{
K T Senzeba, S Rajkumari, A Bhadra and A Bandyopadhyay* \\ Department of Agricultural Engineering, North Eastern Regional Institute of Science and Technology, \\ Nirjuli (Itanagar), Arunachal Pradesh 791109, India. \\ *Corresponding author. e-mail: arnabbandyo@yahoo.co.in
}

Snowmelt run-off model (SRM) based on degree-day approach has been employed to evaluate the change in snow-cover depletion and corresponding streamflow under different projected climatic scenarios for an eastern Himalayan catchment in India. Nuranang catchment located at Tawang district of Arunachal Pradesh with an area of $52 \mathrm{~km}^{2}$ is selected for the present study with an elevation range of 3143-4946 m above mean sea level. Satellite images from October to June of the selected hydrological year 2006-2007 were procured from National Remote Sensing Centre, Hyderabad. Snow cover mapping is done using NDSI method. Based on long term meteorological data, temperature and precipitation data of selected hydrological year are normalized to represent present climatic condition. The projected temperature and precipitation data are downloaded from NCAR's GIS data portal for different emission scenarios (SRES), viz., A1B, A2, B1; and IPCC commitment (non-SRES) scenario for different future years (2020, 2030, 2040 and 2050). Projected temperature and precipitation data are obtained at desired location by spatially interpolating the gridded data and then by statistical downscaling using linear regression. Snow depletion curves for all projected scenarios are generated for the study area and compared with conventional depletion curve for present climatic condition. Changes in cumulative snowmelt depth for different future years are highest under A1B and lowest under IPCC commitment, whereas A2 and $\mathrm{B} 1$ values are in-between $\mathrm{A} 1 \mathrm{~B}$ and IPCC commitment. Percentage increase in streamflow for different future years follows almost the same trend as change in precipitation from present climate under all projected climatic scenarios. Hence, it was concluded that for small catchments having seasonal snow cover, the total streamflow under projected climatic scenarios in future years will be primarily governed by the change in precipitation and not by change in snowmelt depth. Advancing of depletion curves for different future years are highest under A1B and lowest under IPCC commitment. A2 and B1 values are in-between A1B and IPCC commitment.

\section{Introduction}

Global warming is a gradual increase in the average temperature of earth's atmosphere over time. It is the primary effect of having excessive quantities of greenhouse gases in earth's atmosphere. These gases act as blanket, trapping radiation and thereby warming the earth's atmosphere. The increased concentration of greenhouse gases in the atmosphere due to industrial activities results in heat trapping effect, which compounds over time. Finally it leads to global warming and causes global climate change. Many scientists and researchers all over the world are debating on global warming

Keywords. Snowmelt run-off model; streamflow response; climate change scenarios; degree-day approach; snow-cover depletion; snowmelt depth. 
and agree that the earth is gradually warming. Global warming has significant impact over the glaciers and snow-covered regions at high altitudes around the world. The major river systems of the Indian subcontinent, which are originating from the Himalayas, are expected to be more vulnerable to climate change because of substantial contribution from snow and glaciers into these perennial river systems. The areas covered by snow at low altitudes like eastern Himalaya are expected to be most vulnerable to global warming. Increasing agricultural, domestic and industrial needs are directly impacting these available water resources further.

Hydrological models are being increasingly used for predicting the climate affected run-off. For better results, the modelling requires large amount of hydrologic data and system information. Since most of the snow-fed or glacier-fed river basins at high altitudes do not have good network of hydrometeorological stations, liable mathematical model with strong snow and glacier melt simulation capacitiesis are very much essential. It should be able to handle poorly gauged catchment with sparse data. Gautam et al. (2013) reported a greater increasing trend of observed temperature in Nepal and Chinese regions of the Himalayas compared to rest of the Himalayas. They show that glaciers in both the eastern and western Himalayas are mostly retreated. Shrinkage of glacier leads to shortage of water supply for power generation and irrigation in winter.

Dash et al. (2007) found a rising trend of maximum temperature by $1^{\circ} \mathrm{C}$ in the northeast India. Bates et al. (2008) indicated that the best estimated linear trend in global surface temperature from 1906 to 2005 is a warming of $0.74^{\circ} \mathrm{C}$ (ranges from $0.56^{\circ}$ to $0.92^{\circ} \mathrm{C}$ ), with a higher warming trend over the past 50 years. According to MOEF (2011), the maximum and minimum temperature are projected to increase by $2.2^{\circ}-2.8^{\circ} \mathrm{C}$ and $1^{\circ}-$ $2.6^{\circ} \mathrm{C}$ during $2050 \mathrm{~s}$ respectively and towards $2080 \mathrm{~s}$ the projected increase is by $3.4^{\circ}-5^{\circ} \mathrm{C}$ and $2.8^{\circ}-5^{\circ} \mathrm{C}$. Annual precipitation is projected to decrease by 5 to $15 \%$ in the 2050 s and towards 2080 s an increase by $25-35 \%$. Trend analysis of temperature data showed that all the four temperature variables (maximum, minimum and mean temperatures and temperature range) have rising trend over northeast region of India (Jain et al. 2012).

Hong and Guodong (2003) verified the performance of SRM for the Gongnaisi river basin in China. Simulation study on change in snow cover and snowmelt run-off under climate change indicated that snow cover was sensitive to increase of temperature which caused time shifting of snowmelt run-off in early spring month, resulting in a redistribution of seasonal run-off throughout the whole snowmelt season. Sorman et al. (2011) applied
WinSRM in Upper Euphrates basin in Turkey to forecast run-off with a 2-day lead time for snowmelt period. They reported promising results and indicated possible operational use of run-off forecasting for future flood events. Abudu et al. (2012) reported that the applications of SRM in mountainous watersheds of northern China were relatively acceptable although most of the watersheds were having sparse data availability. Future research could explore utilization of snow and glacier cover remote sensing data and GIS tools, field measurement and innovative ways of model parameterization. Ma et al. (2013) considered four scenarios for analysing climate change impact in an ungauged mountainous watershed in northwest China. Results showed that watershed hydrology would alter under different climate change scenarios.

In the present study, the Windows-based snowmelt run-off model (WinSRM) based on degree-day approach has been employed. Snowmelt-Runoff Model (SRM) is designed to simulate and forecast daily streamflow in mountain basins. It is a well-accepted and popular model because of its simplicity, capability to work under limited data availability, and ability to analyse the potential impact of climate change. Satellite images from remote sensing observations are particularly useful for providing spatially-distributed snow cover input data for snowmelt run-off modelling (Hall et al. 2002; Boudhar et al. 2009). The selected study area is at a remote place having poor network of hydro-meteorological station. The unique topography of the region with varying elevation is suitable for small-scale hydro power projects as it allows generation of high head with minimum inundation. According to $\mathrm{PwC}$ (2010), Arunachal Pradesh state has a great hydro power potential to the order of 55,000 MW which is mostly unexplored. However, assessment of impacts of climate change on water resources through snow and glacier melt modelling studies are lacking in the eastern Himalayan regions. The main aim of this study is to analyse the streamflow response pattern of a small seasonally snow covered eastern Himalayan catchment to projected climate change scenarios.

\section{Data and methodology}

\subsection{Study area}

Nuranang river catchment (figure 1) located at Tawang district of Arunachal Pradesh, India with an area of $52 \mathrm{~km}^{2}$ is selected for the present study. Nuranang river, a tributary to Tawang river, originates from Sela Lake and joins Tawang river as 


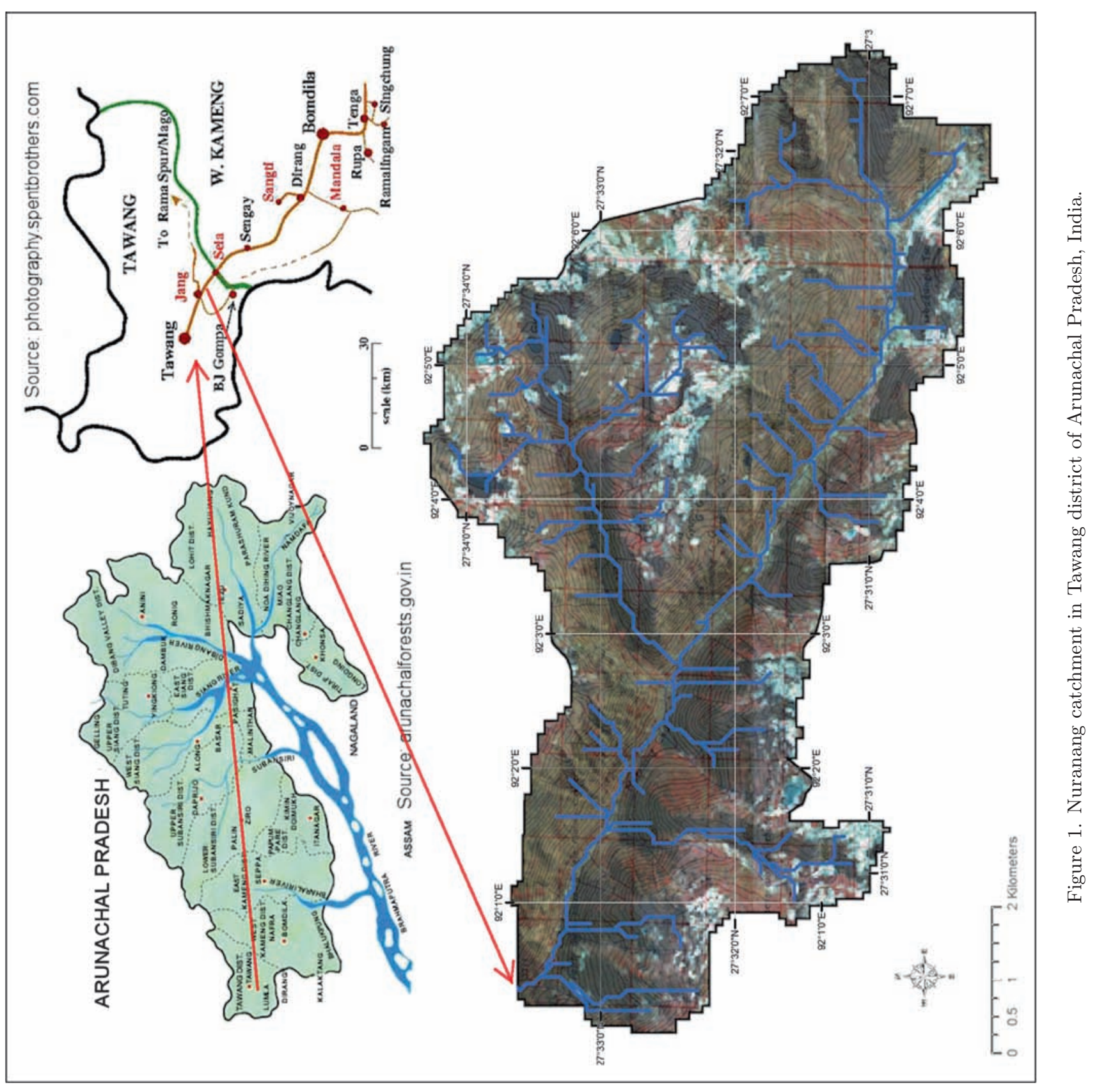


Nuranang Falls at Jang. The altitude of the Sela Lake is $4211 \mathrm{~m}$ above mean sea level (MSL) and it lies at $27^{\circ} 30^{\prime} 15^{\prime \prime} \mathrm{N}$ and $92^{\circ} 06^{\prime} 16^{\prime \prime} \mathrm{E}$. The Central Water Commission (CWC) discharge site at RA-III near Jang is selected as the outlet point and it lies at $27^{\circ} 33^{\prime} 01^{\prime \prime} \mathrm{N}$ and $92^{\circ} 01^{\prime} 13^{\prime \prime} \mathrm{E}$. Elevation of the catchment ranges from 3143 to $4946 \mathrm{~m}$ above MSL with an average slope of $51 \%$. At upper elevation, climate is alpine and at lower elevation, it is temperate. Latitude ranges from $27^{\circ} 30^{\prime}$ to $27^{\circ} 35^{\prime} \mathrm{N}$, whereas longitude is in between $92^{\circ} 00^{\prime}$ and $92^{\circ} 07^{\prime} \mathrm{E}$. Monsoon season is from May to September and having an average annual precipitation of $1139 \mathrm{~mm}$. The entire catchment is dominated by seasonal snow. Snowfall starts from late October and ends at March. Melting of snow starts at February and completely depleted in early June. Snow accumulation and ablation periods vary with years.

\subsection{Data used}

\subsubsection{Satellite images}

Satellite images (LISS-III/AWiFS) for the year 2006-2007 of snow accumulation and depletion period (October-June) are procured from National Remote Sensing Centre (NRSC), ISRO, Hyderabad, India. Shuttle Radar Topography Mission (SRTM) with resolution $90 \mathrm{~m} \times 90 \mathrm{~m}$ digital elevation model (DEM) is downloaded for the study area from http://gisdatadepot.com/dem. Mean hypsometric elevation of the whole catchment is obtained as $4215 \mathrm{~m}$ above MSL from hypsometric (areaelevation) curve (figure 2). Hypsometric curve is generated by plotting the catchment area below a particular elevation against the corresponding elevation. Since the SRM model is sensitive to lapse rate and the CWC meteorological station is located at lower elevation $(3474 \mathrm{~m})$, a lapse rate of $0.5^{\circ} \mathrm{C} / 100 \mathrm{~m}$ (Bandyopadhyay et al. 2014) is used to compute mean daily temperature at hypsometric mean elevation of $4215 \mathrm{~m}$.

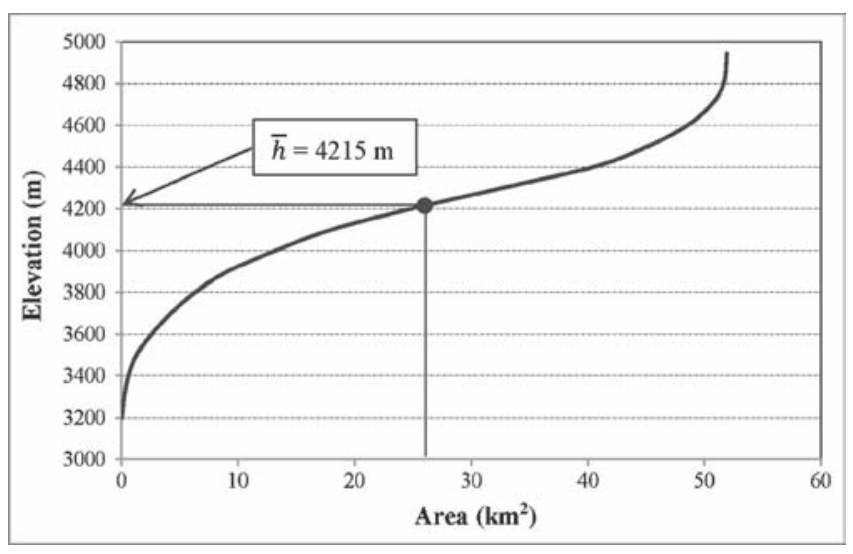

Figure 2. Area-elevation (hypsometric) curve.

\subsubsection{Meteorological and hydrological data}

The meteorological and hydrological data from 2000-2010 measured at CWC discharge site at Jang, Tawang district are collected from CWC office, Itanagar, Arunachal Pradesh, India. The long term average temperature and precipitation data for 2000-2010 show that, in the month of February, the temperature is lowest and then increasing till the mid of August, while the precipitation attains peak in the month of July. These two parameters have a great impact on the rate of depletion of snow.

\subsubsection{Climatic scenarios}

For this study, projected temperature and precipitation data from CCSM3 simulations (Collins et al. 2006) are downloaded as shape files with regular grid points from NCAR's GIS Program Climate Change Scenarios GIS data portal (https:// gisclimatechange.ucar.edu/) for different emission scenarios, viz., A1B, A2, and B1 (SRES; Nakicenovic et al. 2003; Girod et al. 2009); and IPCC commitment scenario (non-SRES scenario; Solomon et al. 2007) for different future years (2020, 2030, 2040, and 2050). The projected temperature and precipitation data at CWC Jang site are obtained by spatially interpolating the gridded data using IDW and then by statistical downscaling using linear regression models developed between past 11 years (2000-2010) CCSM modelled data and observed data at CWC Jang (Swain et al. 2014).

IPCC Special Report on Emissions Scenarios (SRES) (Nakicenovic and Swart 2000) describes that projected scenarios are the product of very complex dynamic systems, determined by driving forces such as demographic development, socioeconomic development, and technological change. Their future evolution is highly uncertain. Main characteristics of A1B scenario include low population growth, very high GDP growth, very high energy use, low-medium land use changes, medium resource (mainly oil and gas) availability, rapid pace and direction of technological change favouring balanced development. B1 scenario includes low population growth, high GDP growth, low energy use, high land use changes, low resource (mainly oil and gas) availability, medium pace and direction of technological change favouring efficiency and dematerialization. A2 scenario includes high population growth, medium GDP growth, high energy use, medium-high land use changes, low resource (mainly oil and gas) availability, slow pace and direction of technological change favouring regional economic development. IPCC commitment scenario assumes that the temperature and precipitation will be restored to normal condition (present condition) within some years. 


\subsection{Snow-cover mapping}

Snow-covered area (SCA) percentage is referred as the areal extent of snow-covered ground which is usually expressed as percentage of total area in a given region. The snow water equivalent (SWE) of the snowpack is important for hydrological modelling and run-off prediction. Snow-covered area is important in hydro-climatic models and in monitoring climate change. The SCA percentages can be estimated using GIS software: ERDAS and ArcGIS. In Himalayas, cloud cover is quite common. In the visible portion of the electromagnetic spectrum, snow and cloud both appear bright white and create confusion in snow-cover area estimation. Mountain shadow also makes it difficult for the delineation of snow-covered areas under mountain shadow from snow-free areas. The normalized difference snow index (NDSI) is useful for the identification of snow as well as for separating snow from clouds. NDSI uses the high and low reflectance of snow in visible (Green) and shortwave infrared (SWIR) bands, respectively, and it can also delineate and map the snow in mountain shadows (Kulkarni et al. 2002). Additionally, the reflectance of clouds remains high in SWIR band, thus NDSI allows discrimination of clouds from snow. The NDSI is estimated using the following equation (Hall et al. 2002; Kulkarni et al. 2002).

$$
\text { NDSI }=\frac{\text { Green Reflectance (B2) }- \text { SWIR (B5) }}{\text { Green Reflectance (B2) }+ \text { SWIR (B5) }}
$$

Kulkarani et al. (2006) showed that the NDSI value can be effectively used to map the aerial extent of snow cover from AWiFS scenes if an appropriate threshold value can be chosen to differentiate SCA from non-snow areas. They suggested that all snow cover areas, including snow in forest and in mountain shadow, can be mapped if the threshold value is kept at 0.4 . In the present study, snow cover area (SCA) percentages on monthly basis are determined from multispectral images (LISS-III/AWiFS) using NDSI technique. NDSI values greater than 0.4 are considered as snow plus water. The water pixels are removed by masking the water bodies which are marked in the pre-winter image. The daily snow-cover area percentages for whole catchment are interpolated from the obtained monthly SCA values (Martinec et al. 2008; Abudu et al. 2012). The snow accumulation and depletion pattern for selected hydrological year 2006-2007 is shown in figure 3 . From the observed mean monthly temperature data (figure 4), it can be noticed that during winter season, the temperature initially decreased in the month of November but then increased in the month of January. Again temperature decreased

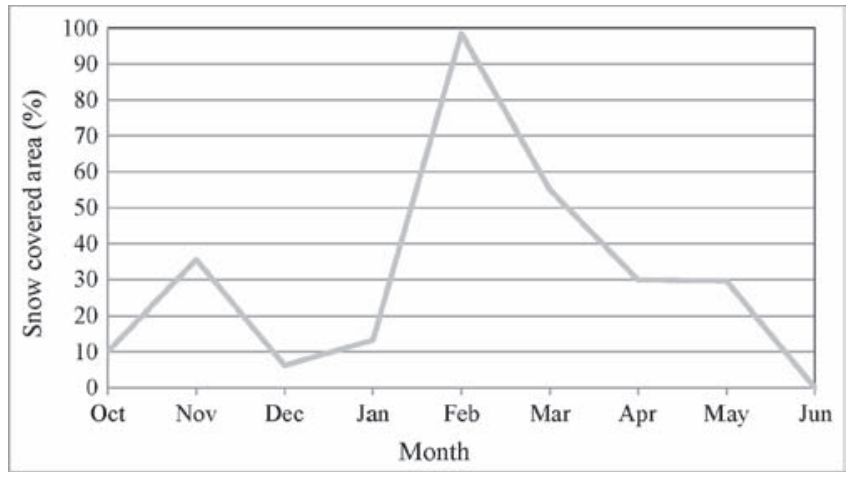

Figure 3. Snow accumulation and depletion pattern for the selected hydrological year (2006-2007).

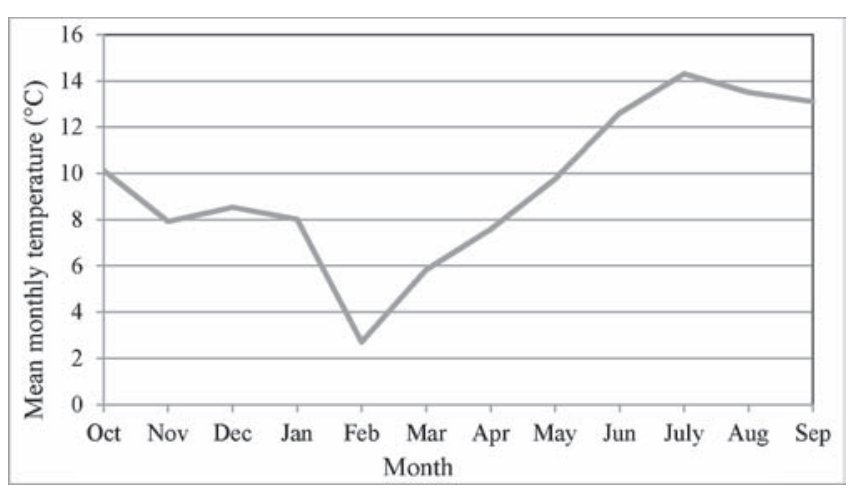

Figure 4. Mean monthly temperature for the selected hydrological year.

during February. Variation of snow-covered area percentage for selected hydrological year (20062007) follow this unique trend (figure 3). Senzeba et al. (2015), after analysing 3 years data, also reported that two SCA\% peaks are common in Nuranang catchment; the first peak occurs around November and the second peak around February, which is larger than first one.

\subsection{Normalization of data for selected hydrological year}

The temperature and precipitation data for the selected hydrological year, i.e., depletion period of 2007 are normalized or rectified to represent the present climatic condition by eliminating the impact of yearly fluctuation of temperature and precipitation on the snow-cover depletion (Martinec et al. 2008). The deviations of monthly average temperature of the selected hydrological year (2007) from long term monthly average temperature for 2000-2010 are determined by the following formula:

$$
\Delta T=\bar{T}_{\text {year }}-\bar{T}_{\text {(long term average) }}
$$


where $\bar{T}_{\text {year }}=$ mean monthly temperature of 2007 and $\bar{T}_{\text {(long term average) }}=$ long term average for 2000 2010.

Then, the daily temperatures of the selected hydrological year are rectified/adjusted with monthly fluctuations preserved.

$$
T_{\text {norm }}=T_{\text {year }}-\Delta T
$$

where $T_{\text {year }}=$ daily temperature of year 2007 .

Ratios of long term monthly mean precipitation for 2000-2010 to the monthly mean precipitation of the selected hydrological year (2007) is determined using following equation:

$$
r=\frac{\bar{P}_{\text {(long term average) }}}{\bar{P}_{\text {year }}}
$$

where $\bar{P}_{\text {year }}=$ mean monthly precipitation of 2007 and $\bar{P}_{(\text {long term average })}=$ long term monthly mean precipitation for $2000-2010$.

The normalized/rectified precipitation value is obtained by adjusting the daily precipitation of the selected hydrological year (2007) with monthly fluctuations preserved.

$$
P_{\text {norm }}=P_{\text {year }} \cdot r
$$

where $P_{\text {year }}=$ daily precipitation data for the year 2007.

Snowmelt depth is obtained by simply multiplying the rectified temperature with degree-day factor $(a)$ as below:

$$
\text { Snowmelt depth }=T_{\text {norm }} \cdot a
$$

where $a=$ degree-day factor, $\mathrm{cm}{ }^{\circ} \mathrm{C}^{-1}$.

When the temperature at a particular day in the depletion period is lower than critical temperature, the rectified precipitation for the corresponding day will be considered as new snow and it contributes to snow melt depth for the next day when rectified temperature exceeds critical temperature. In this study, different projected climatic scenarios (A1B, IPCC commitment, A2 and B1) are considered to evaluate and analyse the responses of streamflow and snow-cover depletion for future years of 2020, 2030, 2040 and 2050.

\subsection{Model structure of WinSRM}

In this study, Windows-based Snowmelt-Runoff Model (WinSRM) (Martinec et al. 2008) is used. WinSRM is designed to simulate and forecast daily streamflow in mountain basins. It can also be applied to evaluate the effect of a changed climate on seasonal snow cover and run-off. The runoff produced from the snowmelt and rainfall can be computed on daily basis, superimposed on the calculated recession flow and transformed into daily discharge from the basin as below:

$$
\begin{aligned}
Q_{n+1}= & {\left[c_{S n} a_{n}\left(T_{n}+\Delta T_{n}\right) S_{n}+c_{R n} P_{n}\right] } \\
& \times \frac{A 10000}{86400}\left(1-k_{n+1}\right)+Q_{n} k_{n+1}
\end{aligned}
$$

where $Q=$ average daily discharge $\left(\mathrm{m}^{3} \mathrm{~s}^{-1}\right) ; c=$ run-off coefficient expressing the losses as a ratio (run-off/precipitation), with $c_{S}$ referring to snowmelt and $c_{R}$ to rain; $a=$ degree-day factor $\left(\mathrm{cm}^{\circ} \mathrm{C}^{-1} \mathrm{~d}^{-1}\right)$ indicating the snowmelt depth resulting from one degree-day; $T=$ number of degree-days $\left({ }^{\circ} \mathrm{C} \mathrm{d}\right) ; \Delta T=$ the adjustment by temperature lapse rate when extrapolating the temperature from the base station to the average hypsometric elevation of the basin or zone $\left({ }^{\circ} \mathrm{C} \mathrm{d}\right)$; $S=$ ratio of the snow-covered area to the total area; $P=$ precipitation contributing to run-off $(\mathrm{cm})$. A pre-selected critical temperature, $T_{\mathrm{CRIT}}$, determines whether this contribution is rainfall and immediate. If precipitation is determined by $T_{\text {CRIT }}$ to be new snow, it is kept on storage over the hitherto snow-free area until melting conditions occur; $A=$ area of the basin or zone $\left(\mathrm{km}^{2}\right) ; k=$ recession coefficient indicating the decline of discharge in a period without snowmelt or rainfall: $k=Q_{\mathrm{m}+1} / Q_{\mathrm{m}}$ $(m, m+1$ are the sequence of days during a true recession flow period); $n=$ sequence of days during the discharge computation period. Please refer to Senzeba et al. (2015) for further details.

\subsection{Model variables and parameters}

The model requires three basic daily values of the input variables, viz., temperature, precipitation and snow-covered area percentage derived from remote sensing observations. Satellite images are used to perform the mapping of snow-covered area. Snow-cover depletion curve (figure 5) is derived to determine the snow coverage on each day by interpolating the monthly percentage of snow-cover area when cloud free scenes are available. The model expresses the temperature as degree-days and it is used to compute the daily snowmelt depths. Model is simulated for the snowmelt season of the selected hydrological year, i.e., 1 February 2007-31st May 2007.

Seven parameters are involved to run the SRM model, viz., run-off coefficients, degree-day factor, temperature lapse rate, critical temperature, rainfall contribution area, recession coefficient and time lag. Analysis of historical discharge data and basin characteristics help in determining the recession coefficients and temperature lapse rate. For Nuranang, average degree-day factor $(a)$ is obtained as $0.3 \mathrm{~cm} /{ }^{\circ} \mathrm{C}$ from snow water equivalent recorder (SWER) installed at Sela top. This average value 
matches quite well with the average of recommended monthly values as suggested by WMO (1964). For the present study, the temperature lapse rate is estimated by simple linear regression for maximum,

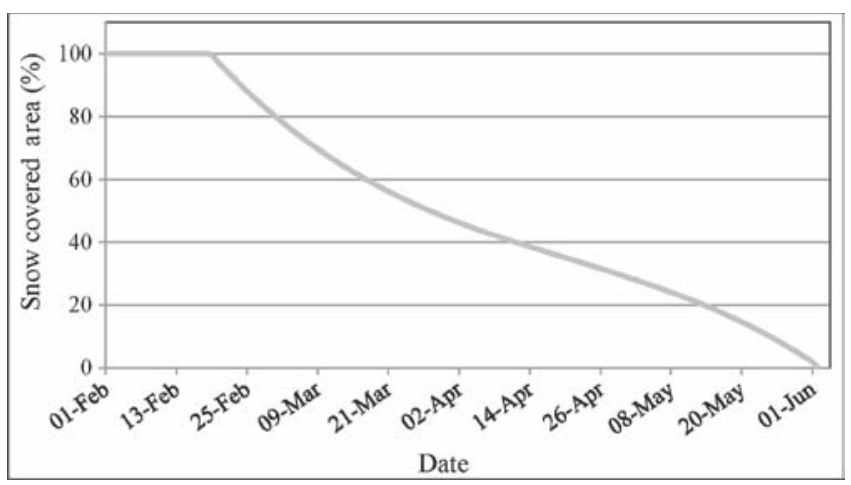

Figure 5. Conventional depletion curve (CDC) for the selected hydrological year 2007. minimum and mean monthly temperatures with altitudes. From linear regression results, an average value of $0.5^{\circ} \mathrm{C} / 100 \mathrm{~m}$ as lapse rate for mean air temperature is considered for the model simulation (Bandyopadhyay et al. 2014). Other five parameters, viz., critical temperature, time lag, run-off coefficients for snowmelt and rain, and rainfall contributing area are calibrated to determine the best possible combination of optimal values. For obtaining best possible combination of those calibration parameters, only one parameter at a time is varied within feasible range keeping other parameters fixed at their starting values. Depending on values of performance indicators model efficiency (ME) and coefficient of residual mass (CRM) on comparing predicted and observed run-off, the best possible combinations of calibration parameters are determined and the model is simulated using best possible set of calibration parameter. The best possible

Table 1. Model parameters for the selected hydrological year.

\begin{tabular}{lll}
\hline Parameter & Range & Value \\
\hline Determined & & Feb $=0.1$ \\
Degree day factor, $\mathrm{cm} /{ }^{\circ} \mathrm{C}$ & & $\mathrm{Mar}=0.1$ \\
& & $\mathrm{Apr}=0.3$ \\
& & $\mathrm{May}=0.4$ \\
& & $\mathrm{Jun}=0.6$ \\
Recession coefficients & & $\mathrm{x}=0.61$ \\
& & $\mathrm{y}=0.104$ \\
Temperature lapse rate, ${ }^{\circ} \mathrm{C} / 100 \mathrm{~m}$ & & 0.5 \\
Calibrated & & \\
Tcrit, ${ }^{\circ} \mathrm{C}$ & $0-5$ & 1 \\
Lag time $(\mathrm{L}), \mathrm{h}$ & $2-12$ & 2 \\
Run-off coefficient for snowmelt $\left(\mathrm{c}_{S}\right)$ & $0.1-1$ & 0.1 \\
Run-off coefficient for rain $\left(\mathrm{c}_{R}\right)$ & $0.1-1$ & 0.9 \\
Rainfall contributing area $(\mathrm{RCA})$ & 0,1 or mix & Mix \\
ME & & 0.69 \\
CRM & & -0.08 \\
\hline
\end{tabular}
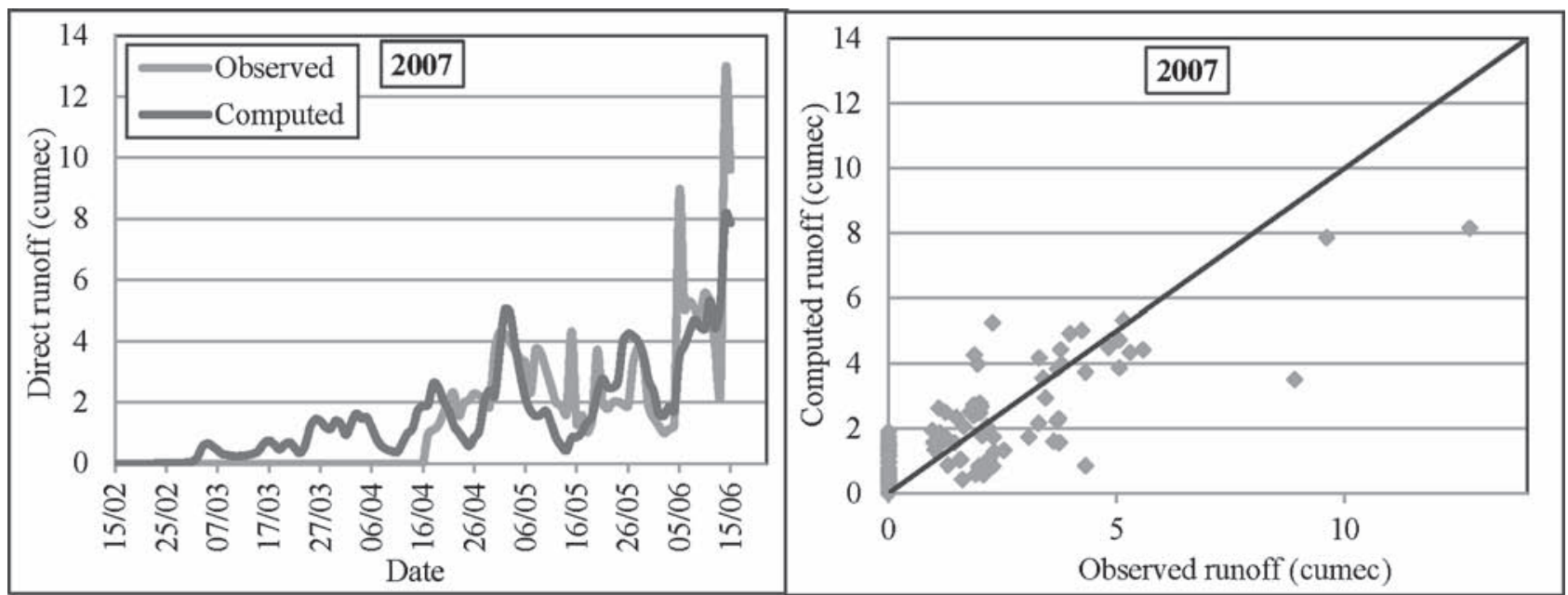

Figure 6. Time series and scatter plots for selected hydrological year 2007. 


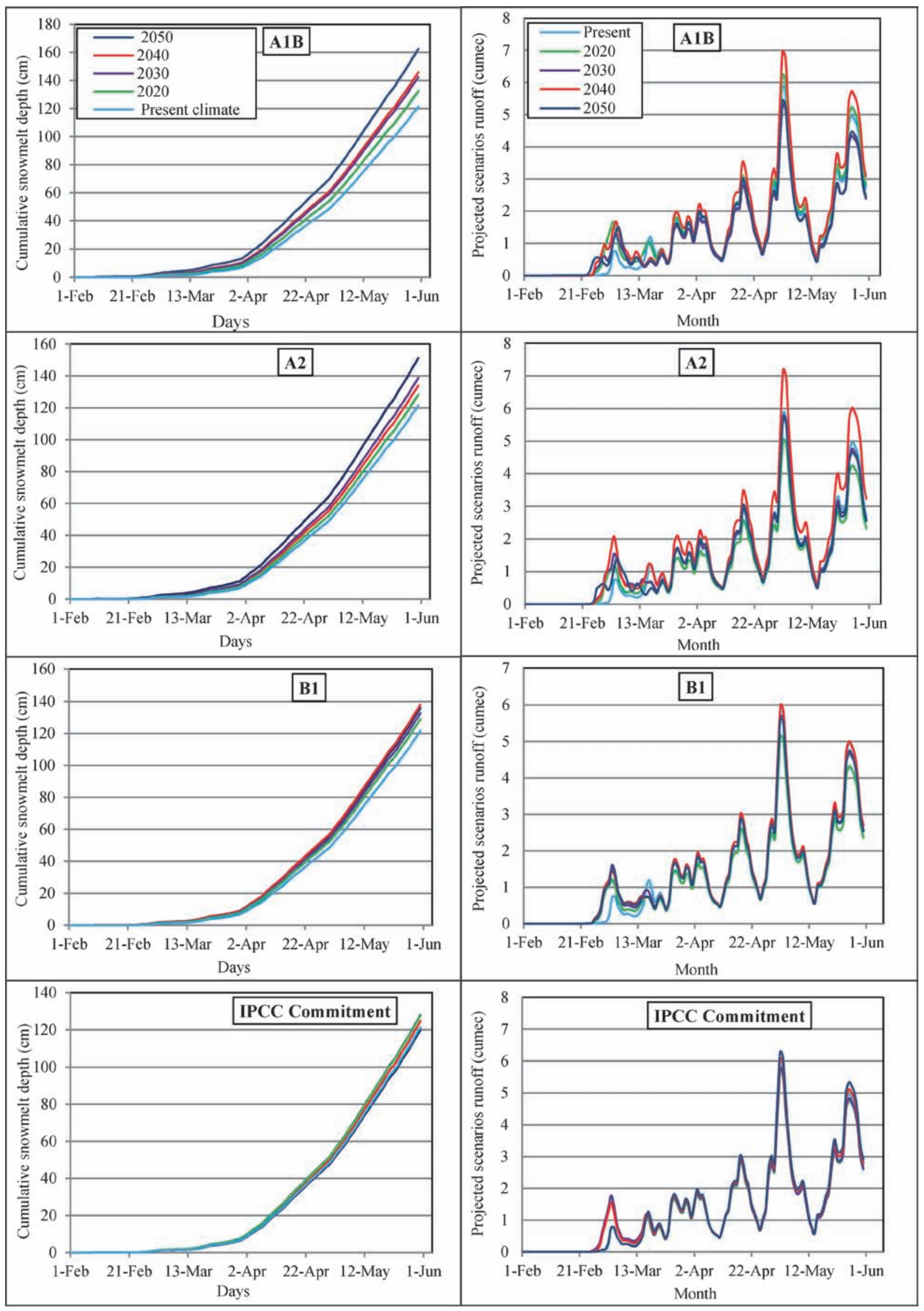

Figure 7. Projected cumulative snowmelt depth and daily streamflow under projected scenarios for different future years. 
set of calibration parameter and calibration result is shown in table 1 and figure 6. Further details on this modelling exercise are given in Senzeba et al. (2015), from which some idea about the sensitivity of the calibration parameters to the SRM model can also be obtained. It may be noted that, only the temperature and precipitation were considered to represent the future climate while developing the climate affected depletion curve, as described in the next section, which is a limitation of this study. Further, the baseflow was separated from the observed streamflow following Hughes et al. (2003) and Welderufael and Woyessa (2010) which might have removed some amount of direct runoff during lean season causing zero observed direct run-off prior to 16th April (figure 6). But during that period, SRM predicted some direct run-off. Again after 5th June, the observed direct run-off seems to be very high compared to SRM simulated one. That may be because of melt water contribution from various high altitude frozen lakes to the streamflow, which could not be considered in the model.

\subsection{Development of climate affected depletion curve}

For the selected hydrological year 2007, by interpolating monthly SCA percentages, conventional depletion curve (CDC) is generated by plotting daily snow covered percentage with respect to corresponding days (figure 5). Depletion curves indicated the snow coverage on each day of the melt season. They have been also used as indicator of snow reserves and water equivalent. But decline of snow cover extent not only depends on the initial snow reserves, but also on the climatic conditions of the year being considered. Therefore, a modified depletion curve has been proposed to normalize such differences between different years to represent present climatic condition following the procedure outlined in Rango and Martinec (1994) and Martinec et al. (2008). The future course of the depletion curve of the snow coverage can be evaluated from the modified depletion curves (MDC). This curve can be derived from the CDC by replacing the time scale with cumulative daily snowmelt depth. In a warmer climate, this cumulative snowmelt depth will be reached at an earlier date and the conventional depletion curve of the snow coverage will be shifted accordingly. Using this climate-affected convention depletion curves together with precipitation and temperature given by a projected climate scenarios, the future changed run-off can be computed. Modified depletion curves of snow-covered area for a changed climate take into account the amount of snowfall changed by the new climate. The shifting of date of snow depletion curve under different projected climatic scenarios (A1B, A2, B1 and IPCC commitment) for different future years 2020, 2030, 2040 and 2050 are determined as described by Rango and Martinec (1994), and Martinec et al. (2008). Climate affected depletion curves are obtained by plotting the daily value of SCA\% against the shifted date of snow depletion due to changed climate. These curves indicated the change in duration of snow depletion period, its start and end time and change in the rate of depletion under projected climatic scenarios. The derived climate affected depletion curves due to climate change under different projected climatic scenarios (A1B, A2, B1 and IPCC commitment) for different future years $(2020,2030,2040$, and 2050) are used as model input along with changed temperature and precipitation to compute the climate-affected runoff. The simulation results of the model provide the difference between the run-off computed for the selected hydrological year (which represented the present climate) and run-off obtained for different projected climate scenarios.

Table 2. Comparison of projected snowmelt depth and streamflow with present climate.

\begin{tabular}{|c|c|c|c|c|c|c|c|c|}
\hline \multirow[b]{2}{*}{ Year } & \multicolumn{2}{|c|}{$\mathrm{A} 1 \mathrm{~B}$} & \multicolumn{2}{|c|}{$\mathrm{A} 2$} & \multicolumn{2}{|c|}{ B1 } & \multicolumn{2}{|c|}{ IPCC } \\
\hline & $\mathrm{ME}$ & CRM & $\mathrm{ME}$ & CRM & $\mathrm{ME}$ & CRM & $\mathrm{ME}$ & CRM \\
\hline \multicolumn{9}{|c|}{ Snowmelt depth } \\
\hline 2020 & 0.980 & -0.110 & 0.990 & -0.070 & 0.990 & -0.080 & 0.990 & -0.060 \\
\hline 2030 & 0.940 & -0.220 & 0.960 & -0.180 & 0.980 & -0.120 & 0.990 & -0.070 \\
\hline 2040 & 0.920 & -0.250 & 0.980 & -0.130 & 0.960 & -0.170 & 1.000 & -0.030 \\
\hline 2050 & 0.760 & -0.430 & 0.870 & -0.310 & 0.970 & -0.150 & 1.000 & 0.020 \\
\hline \multicolumn{9}{|c|}{ Streamflow } \\
\hline 2020 & 0.970 & -0.100 & 0.953 & 0.100 & 0.961 & 0.081 & 0.980 & -0.006 \\
\hline 2030 & 0.962 & 0.063 & 0.973 & -0.031 & 0.976 & -0.018 & 0.978 & -0.029 \\
\hline 2040 & 0.915 & -0.199 & 0.882 & -0.253 & 0.975 & -0.064 & 0.984 & -0.062 \\
\hline 2050 & 0.962 & 0.025 & 0.972 & -0.008 & 0.974 & -0.010 & 0.991 & -0.059 \\
\hline
\end{tabular}




\section{Results and discussion}

\subsection{Change in cumulative snowmelt depth and streamflow}

Figure 7 shows the cumulative snowmelt depth curves for present climate (selected hydrological year 2007) and different future years $(2020,2030$, 2040 , and 2050) under projected climatic scenarios. With variations in temperature and precipitation under projected climatic scenarios for future years of 2020, 2030, 2040, and 2050, the cumulative snowmelt depth also varies. In 2020, the increased temperature is minimal so the melt depth under all projected scenarios closely corresponds to the present-climate melt depth. In 2030, as the temperature further increased, the melt depth of all scenarios also increased. In 2040, melt depth under $\mathrm{A} 1 \mathrm{~B}$ is highest followed by B1 then A2. Melt depths under IPCC commitment scenario stayed close to present climate in all future years. In 2050, the projected cumulative snowmelt depth under A1B is found highest that crossed $160 \mathrm{~cm}$, followed by A2 in which cumulative melt depth reached $150 \mathrm{~cm}$ and B1 with cumulative melt depth as $135.91 \mathrm{~cm}$. In case of IPCC commitment scenario, the projected temperature decreases in 2050 from present climate and its effect is reflected in cumulative snowmelt depth which is lesser than the melt depth in present climatic condition. The above facts are also apparent from table 2 in which the modelling efficiency (ME) and coefficient of residual mass (CRM) computed between projected and presentclimate melt depths are presented. It may be noted that a higher ME (close to 1.0) indicates a higher match between the two. On the other hand, for a perfect match, the value of CRM will be zero. A positive value of CRM indicates underprojection, whereas, a negative value indicates overprojection compared to present-climate snowmelt depth. For different future years, it can be said that projected cumulative snowmelt depths are maximum under $\mathrm{A} 1 \mathrm{~B}$ and minimum under IPCC commitment. A2 and $\mathrm{B} 1$ values are in-between $\mathrm{A} 1 \mathrm{~B}$ and $\mathrm{IPCC}$ commitment.

Figure 7 and table 2 also show the projected streamflow due to changed climate in different future years in comparison with the run-off for present climatic condition along with cumulative snowmelt depth on each day of depletion period. It can be observed that, under all projected scenarios for different future years, the effects of increased cumulative snowmelt depth are not directly reflected into the projected streamflow. Under A1B and A2 scenarios, the cumulative melt depth is highest in 2050 but it is not reflected in streamflow of 2050. Instead, the streamflow in 2050 decreases further from the present-climate streamflow at the end of snow depletion period. Under B1 scenario, the streamflow closely corresponds to cumulative snowmelt depth. And under IPCC commitment scenario, in 2050 the cumulative snowmelt depth decreases from the present climate but the streamflow is more than present climate. But, IPCC commitment is the only scenario which is closely comparable to present climatic condition.

The variation of changes in cumulative snowmelt depth on 31st May under different projected scenarios is illustrated in figure 8. As expected, the change in cumulative snowmelt depth follows the same trend as change in temperature from present climatic condition in different future years under all projected scenarios (table 3 ). The variation

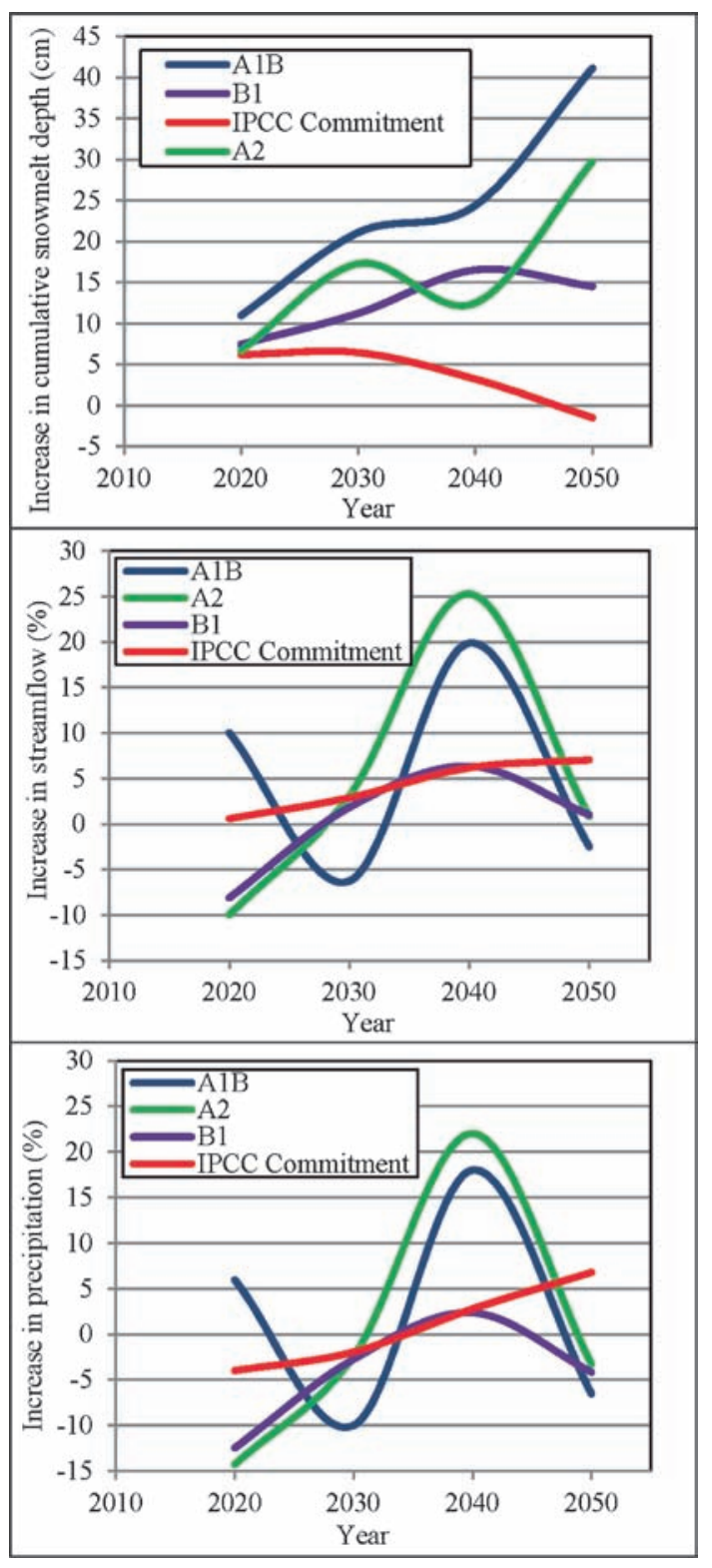

Figure 8. Increase in cumulative snowmelt depth and streamflow volume as compared to increase in precipitation from present climate on 31st May. 
Table 3. Change in depletion pattern and streamflow under changed temperature and precipitation.

\begin{tabular}{|c|c|c|c|c|c|c|c|c|c|c|}
\hline \multirow[b]{3}{*}{ Scenario } & \multirow[b]{3}{*}{ Year } & \multirow{3}{*}{$\begin{array}{c}\text { Increase in } \\
\text { precipitation } \\
(\%)\end{array}$} & \multirow{3}{*}{$\begin{array}{c}\text { Increase in } \\
\text { temperature } \\
\left({ }^{\circ} \mathrm{C}\right)\end{array}$} & \multirow{3}{*}{$\begin{array}{l}\text { Increase in } \\
\text { cumulative } \\
\text { snowmelt } \\
\text { depth on 31st } \\
\text { May }(\mathrm{cm})^{*}\end{array}$} & \multirow{3}{*}{$\begin{array}{c}\text { Increase in } \\
\text { streamflow } \\
\text { volume }(\%)^{*}\end{array}$} & \multicolumn{2}{|c|}{ Depletion } & \multicolumn{2}{|c|}{ Shifting } & \multirow{3}{*}{$\begin{array}{c}\text { Duration } \\
\text { (days) }\end{array}$} \\
\hline & & & & & & \multicolumn{2}{|c|}{ Present condition } & $\begin{array}{l}\text { Start } \\
\text { date }\end{array}$ & $\begin{array}{l}\text { End } \\
\text { date }\end{array}$ & \\
\hline & & & & & & 19th Feb & 2nd Jun & (days) & (days) & \\
\hline \multirow[t]{4}{*}{$\mathrm{A} 1 \mathrm{~B}$} & 2020 & 6 & 0.44 & 10.98 & 10.03 & 9th Feb & 31st May & 10 & 2 & 112 \\
\hline & 2030 & -10 & 0.84 & 21.08 & -6.26 & 10th Feb & 26th May & 9 & 7 & 106 \\
\hline & 2040 & 18 & 0.97 & 24.38 & 19.87 & 10th Feb & 26th May & 9 & 7 & 106 \\
\hline & 2050 & -7 & 1.62 & 41.11 & -2.48 & 10th Feb & 19th May & 9 & 14 & 99 \\
\hline \multirow[t]{4}{*}{ A2 } & 2020 & -14 & 0.27 & 6.70 & -9.98 & 9th Feb & 31st May & 10 & 2 & 112 \\
\hline & 2030 & -2 & 0.69 & 17.28 & 3.09 & 9th Feb & 28th May & 10 & 5 & 109 \\
\hline & 2040 & 22 & 0.50 & 12.50 & 25.28 & 9th Feb & 31st May & 10 & 2 & 112 \\
\hline & 2050 & -3 & 1.18 & 29.72 & 0.81 & 10th Feb & 24th May & 9 & 9 & 104 \\
\hline \multirow[t]{4}{*}{ B1 } & 2020 & -12 & 0.30 & 7.46 & -8.10 & 9th Feb & 31st May & 10 & 2 & 112 \\
\hline & 2030 & -3 & 0.45 & 11.24 & 1.83 & 9th Feb & 30th May & 10 & 3 & 111 \\
\hline & 2040 & 2 & 0.66 & 16.53 & 6.36 & 9th Feb & 29th May & 10 & 4 & 110 \\
\hline & 2050 & -4 & 0.58 & 14.51 & 1.02 & 9th Feb & 29th May & 10 & 4 & 110 \\
\hline \multirow[t]{4}{*}{ IPCC } & 2020 & -4 & 0.25 & 6.2 & 0.59 & 9th Feb & 1st June & 10 & 1 & 113 \\
\hline & 2030 & -2 & 0.26 & 6.45 & 2.89 & 9th Feb & 1st June & 10 & 1 & 113 \\
\hline & 2040 & 3 & 0.13 & 3.22 & 6.19 & 9th Feb & 2nd June & 10 & 0 & 114 \\
\hline & 2050 & 7 & -0.06 & -1.49 & 5.94 & 23rd Feb & 3rd June & -4 & -1 & 101 \\
\hline
\end{tabular}

${ }^{*}$ Cumulative snowmelt depth $=121.40 \mathrm{~cm}$ and total streamflow volume $=13.66 \mathrm{M} \mathrm{m}^{3}$ under present climatic condition $(1$ February-31 May).

of increase in total streamflow for the simulation period under different projected scenarios is also illustrated in figure 8 . The percentage change in total streamflow volume from present climatic condition follows almost the same trend as change in precipitation from present climatic condition in different future years under all projected scenarios (figure 8 and table 3). But, the percentage change in total streamflow volume from present climatic condition does not follow the trends of cumulative snowmelt depth. So, it can be concluded from this study that for this small eastern Himalayan catchment having seasonal snow cover, the total streamflow under projected climatic scenarios in future years will be primarily governed by the change in precipitation and not by change in snowmelt depth.

Among different future years of 2020, 2030, 2040 and 2050, percentage increase in streamflow volume is maximum in 2040 under all projected scenarios. Among different scenarios, in 2040, increase in streamflow is highest for A2 scenario followed by $\mathrm{A} 1 \mathrm{~B}, \mathrm{~B} 1$, and IPCC commitment. But, increase in precipitation is highest for A2 scenario followed by A1B, IPCC commitment, and B1. Effect of change in cumulative snowmelt depth is visible on change in streamflow when increase in precipitation is almost same for two future scenarios (e.g., for B1 and IPCC commitment scenarios in 2040).

\subsection{Climate-affected depletion curves and time shifting of streamflow}

Depletion patterns under different projected scenarios differ from conventional depletion curve (CDC). Using climate-affected conventional depletion curves $\left(\mathrm{CDC}_{\mathrm{CLIM}}\right)$ along with projected temperature and precipitation, streamflows are simulated at the outlet of the basin for different future years under projected climatic scenarios. Climate-affected depletion curves along with climate-affected simulated streamflow for future years 2020, 2030, 2040, and 2050 under different projected scenarios are shown in figure 9. It can be inferred from figure 9 that for all future years, the A1B climatic scenario affects the snow-cover depletion most, as a result, the depletion of snow completes faster in this scenario. Climate-affected depletion curve under IPCC commitment almost matches with CDC for present climate. Climate-affected depletion curves under A2 and $\mathrm{B} 1$ scenarios are in between $\mathrm{A} 1 \mathrm{~B}$ and IPCC commitment.

Compared to present climatic condition (where depletion starts on 19 February), the shift of start and end dates of the snow-cover depletion curves for different future years under projected climatic scenarios are given in table 3 . Under $\mathrm{A} 1 \mathrm{~B}$, the start date of depletion shifts back from 10 days in 2020 to nine days in 2050; the end date shifts back from two days in 2020 to 14 days in 2050; 


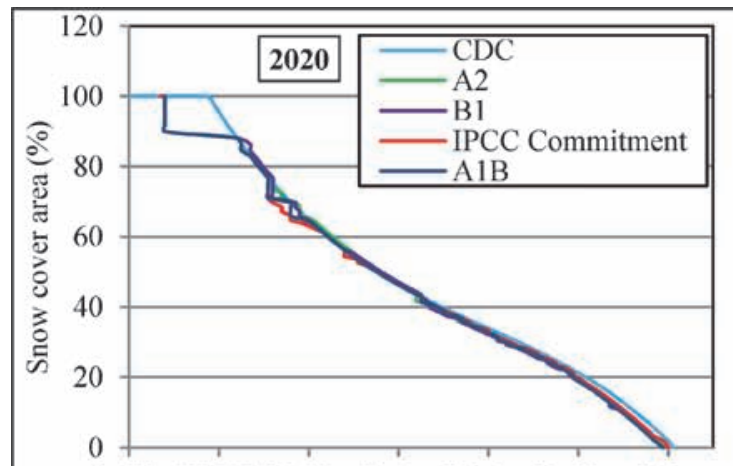

1-Feb 21-Feb 13-Mar 2-Apr 22-Apr12-May 1-Jun

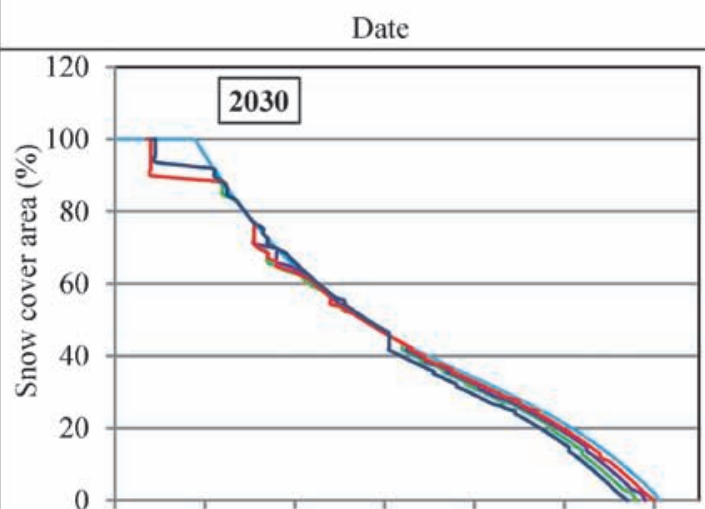

1-Feb 21-Feb13-Mar 2-Apr 22-Apr12-May 1-Jun

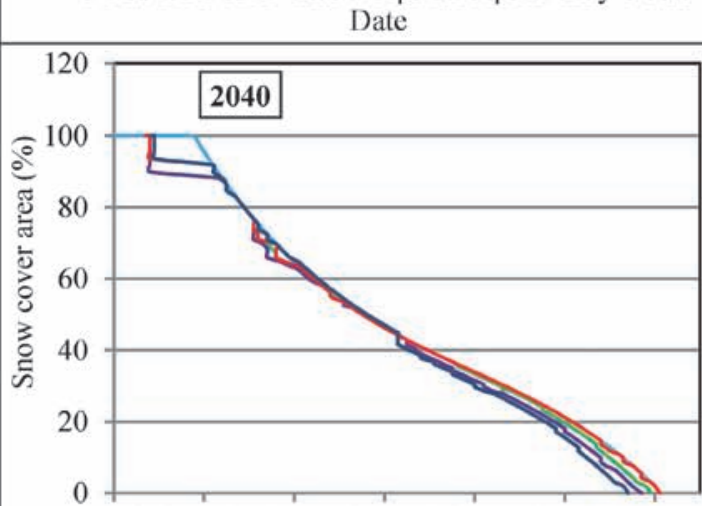

1-Feb 21-Feb 13-Mar 2-Apr 22-Apr12-May 1-Jun

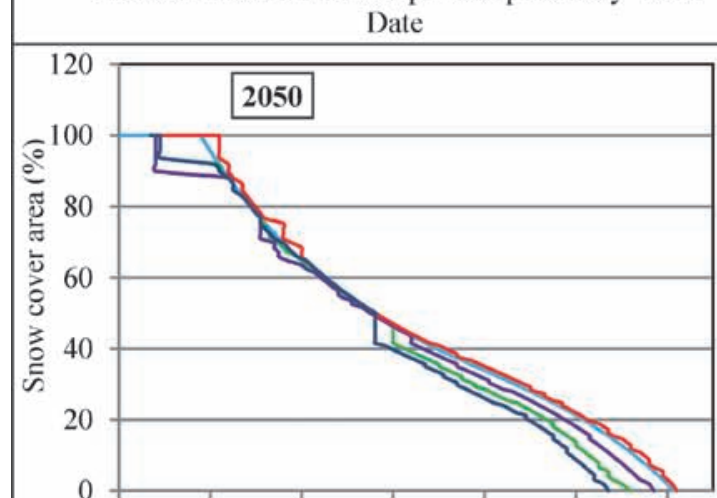

1-Feb 21-Feb 13-Mar 2-Apr 22-Apr12-May 1-Jun Date

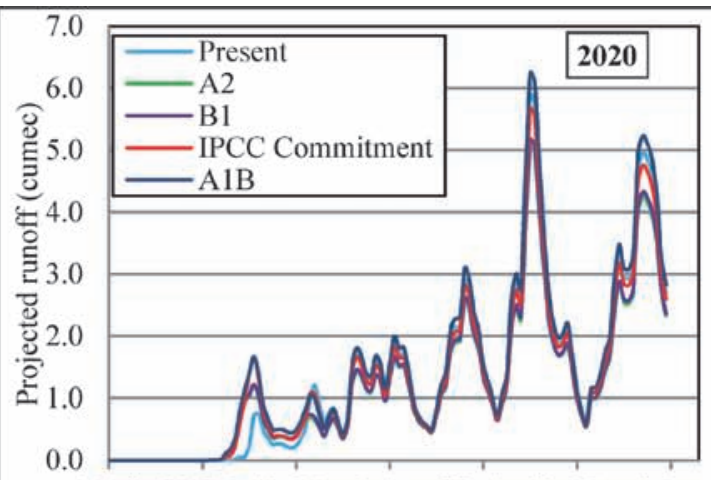

1-Feb 21-Feb 13-Mar 2-Apr 22-Apr 12-May 1-Jun Date

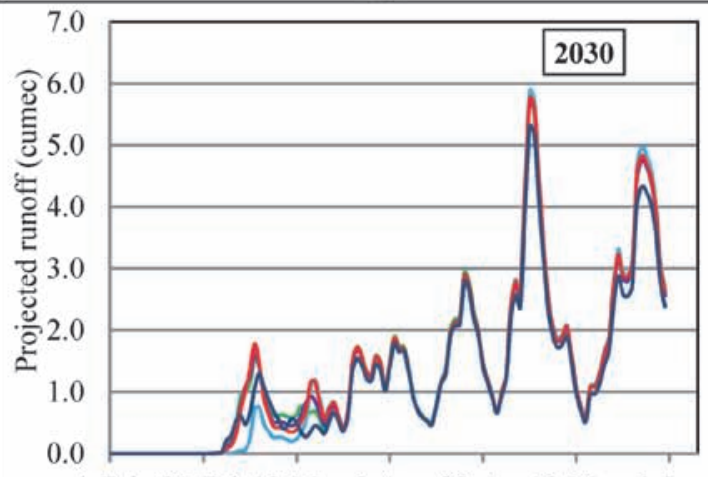

1-Feb 21-Feb 13-Mar 2-Apr 22-Apr12-May 1-Jun Date

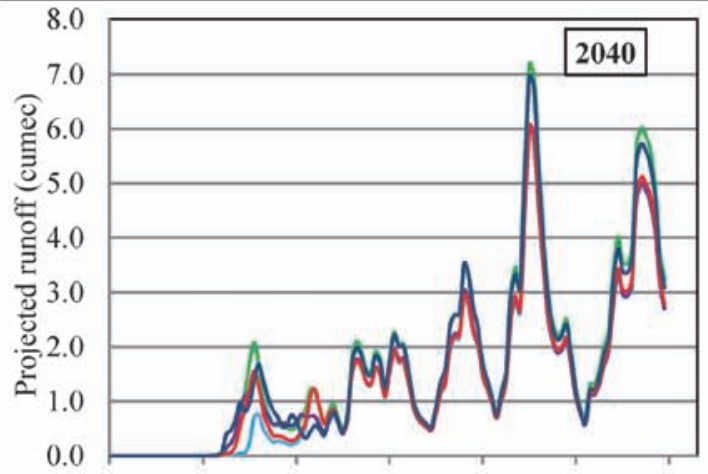

1-Feb 21-Feb 13-Mar 2-Apr 22-Apr 12-May 1-Jun Date

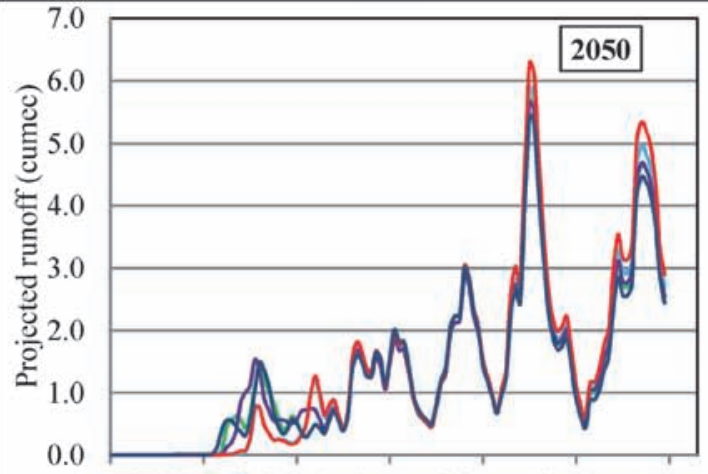

1-Feb 21-Feb 13-Mar 2-Apr 22-Apr 12-May 1-Jun Date

Figure 9. Climate affected depletion curve and streamflow under projected climatic scenarios for different future years. 
modifying the snowmelt period from 112 days in 2020 to 99 days in 2050 . Under A2, the start date of depletion shifts back from 10 days in 2020 to nine days in 2050; the end date shifts back from two days in 2020 to nine days in 2050; modifying the duration of snow-melt period from 112 days in 2020 to 104 days in 2050. Under B1, the start date of depletion shifts back 10 days for all the future years; backward shifting of end date varies from two days in 2020 to four days in 2050; and the duration of snow-melt period varies from 112 days in 2020 to 110 days in 2050. Under IPCC commitment, the start date of depletion shifts back 10 days in 2020 whereas shifts forward four days in 2050; similarly, the end date also shifts back one day in 2020 but shifts forward by one day in 2050; resulting the duration of snow-melt period of 113 days in 2020 and 101 days in 2050. Change in start date of snow-cover depletion in future years under different projected scenarios has effect on time shifting of snowmelt run-off in early spring month (figure 9).

Figure 10 compares the backward shifts in end dates with change in temperature over future years under projected climatic scenarios. It can be observed from figure 10 that if temperature increases, shift of end dates in the backward direction increases. For any future year, number of days of backward shift in end dates is highest under A1B and lowest under IPCC commitment scenarios, respectively. Backward shifting of end dates under $\mathrm{A} 2$ and $\mathrm{B} 1$ are in between $\mathrm{A} 1 \mathrm{~B}$ and IPCC commitment. Under IPCC commitment, instead of shifting in backward direction, depletion ends one day ahead compared to present climatic condition in 2050 .

\subsection{Change in snow-cover distribution and streamflow on a particular day}

Figure 11 shows the changed extent of SCA under projected scenarios for different future years in comparison with present climatic condition on a particular date 26th April (randomly selected). It can be observed from figure 11 and table 4 that on that particular day (26th April), under present climatic condition, the snow covered extent is $16.41 \mathrm{~km}^{2}$. Compared to present condition, for different future years, projected climatic scenarios affected the snow cover extent of the catchment. In 2020, the extent of snow cover area is highest under IPCC commitment $\left(15.80 \mathrm{~km}^{2}\right)$ followed by A1B $\left(15.49 \mathrm{~km}^{2}\right)$ scenario. Both A2 and B1 scenarios show the same snow cover extent as $15.18 \mathrm{~km}^{2}$. In 2030, IPCC commitment and B1 show least shrinkage having the same snow cover extent as in 2020 . A1B scenario has the highest shrinkage $\left(13.89 \mathrm{~km}^{2}\right)$ followed by A2 $\left(14.86 \mathrm{~km}^{2}\right)$. But in 2040 , the total snow cover extent is increased under all projected scenarios except B1. Under IPCC commitment,

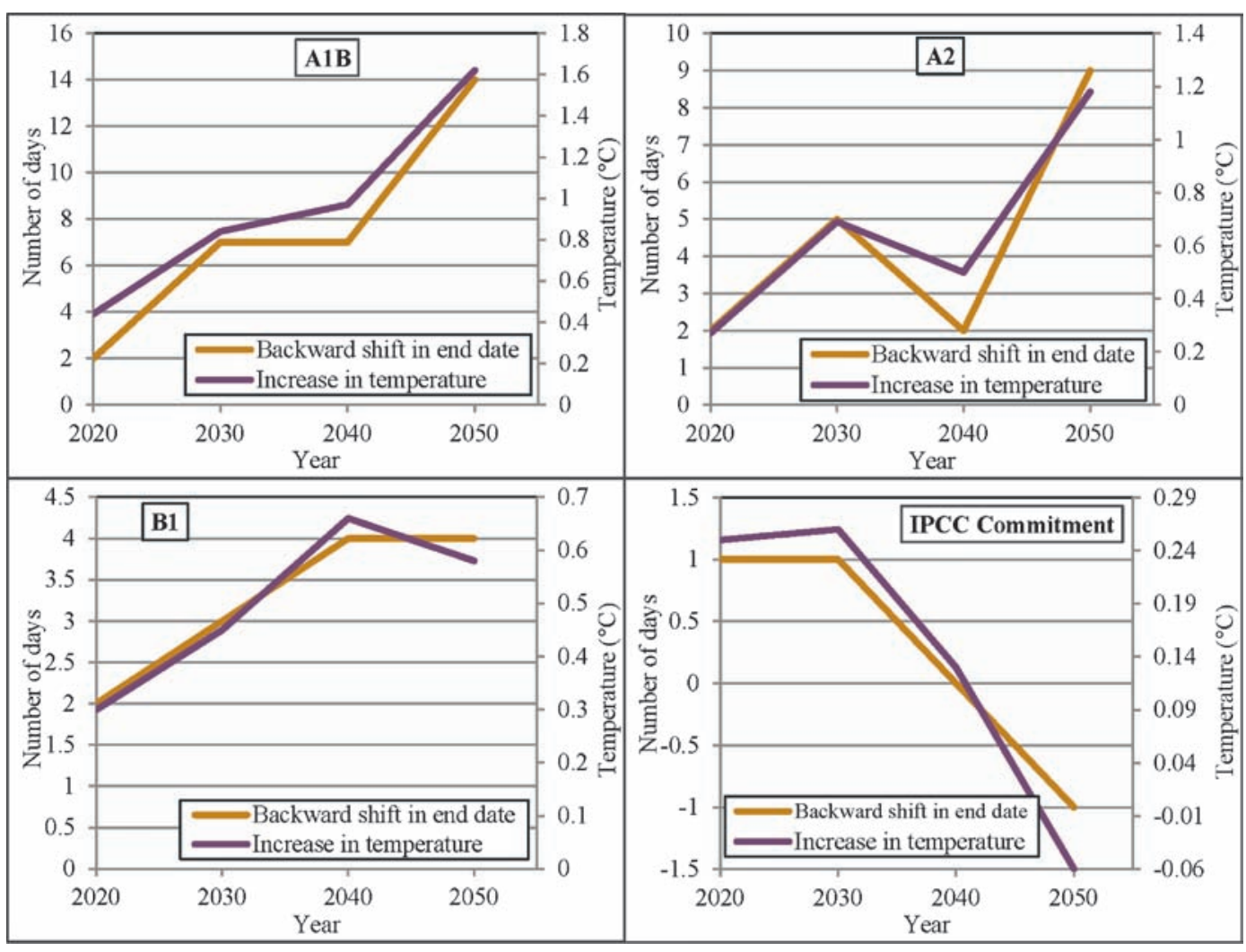

Figure 10. Backward shift in depletion end date with change in temperature. 
the snow extent is same as the present condition $\left(16.41 \mathrm{~km}^{2}\right)$ and the highest decrease in snow cover extent compared to present condition is under A1 followed by B1 and A2 scenarios. In 2050, as expected, A1B has the lowest snow extent of 12.51 $\mathrm{km}^{2}$; followed by $\mathrm{A} 2$ with $13.55 \mathrm{~km}^{2}$; and then B1 having the same snow extent as 2040 (14.86 $\mathrm{km}^{2}$ ). However under IPCC commitment scenario, the snow cover extent shows an increase from the present snow cover extent by $3.7 \%$ because of decreased projected temperature. From the comparative analysis of snow-covered area on a particular day (26th April), it can be observed that

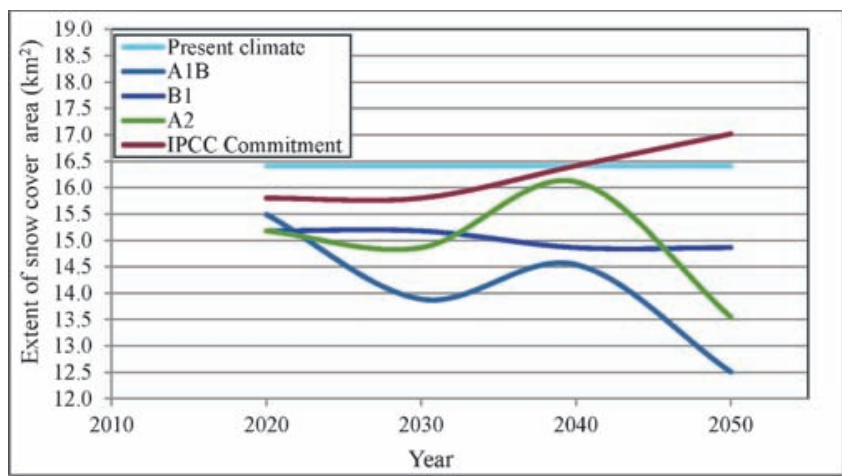

(a) Extent of snow covered area on $26^{\text {th }}$ April

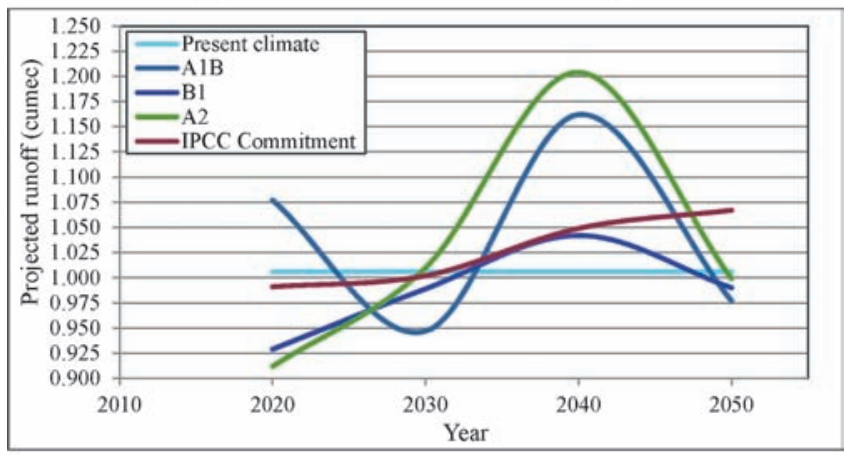

(b) Streamflow on $26^{\text {th }}$ April

Figure 11. Extent of snow-covered area and streamflow on 26th April. in 2050, decrease in SCA are 24\%, $17 \%$ and $10 \%$ with corresponding decrease in streamflow of $3 \%$, $0.7 \%$ and $2 \%$ under $\mathrm{A} 1 \mathrm{~B}, \mathrm{~A} 2$ and $\mathrm{B} 1$ respectively from present climatic condition. Under B1, though projected decrease in $\mathrm{SCA}$ is lesser compared to $\mathrm{A} 2$, but projected decrease in precipitation is more than A2, which results more decrease in streamflow than A2.

\section{Conclusions}

Snow-cover depletion starts in the month of February in the selected eastern Himalayan catchment under present climatic condition. Changes in $\mathrm{cu}-$ mulative snowmelt depth for different future years are highest under A1B and lowest under IPCC commitment. The changes in cumulative snow-melt depth for different future years follow the same trend as change in temperature from present climate under all four projected climatic scenarios. Under IPCC commitment scenario, as the temperature and precipitation are projected to restore the present condition after some years, change in temperature as well as change in cumulative snowmelt depth with respect to present climatic condition decrease with advancement of time. Advancing of depletion curves for different future years are highest under $\mathrm{A} 1 \mathrm{~B}$ and lowest under IPCC commitment. $\mathrm{A} 2$ and $\mathrm{B} 1$ values are in-between $\mathrm{A} 1 \mathrm{~B}$ and IPCC commitment.

Percentage increase in streamflow for different future years follow almost the same trend as change in precipitation from present climate under all four projected climatic scenarios. For the present catchment having seasonal snow cover, the total streamflow under projected climatic scenarios in future years will be primarily governed by the change in precipitation and not by change in snow-melt depth. The effect of change in cumulative snow melt depth is visible on change in streamflow when increase in precipitation is almost same for two future

Table 4. Projected SCA and streamflow on 26th April.

\begin{tabular}{|c|c|c|c|c|c|c|c|c|c|}
\hline & & & & & $\mathrm{SCA}$ & $\left.\mathrm{km}^{2}\right)$ & & & 16.41 \\
\hline & & & & & Streamflo & (cum & & & 1.006 \\
\hline & & & 2020 & & 2030 & & 2040 & & 2050 \\
\hline Under & present climatic condition & & Change (\%) & & Change (\%) & & Change (\%) & & Change (\%) \\
\hline $\mathrm{A} 1 \mathrm{~B}$ & $\mathrm{SCA}\left(\mathrm{km}^{2}\right)$ & 15.49 & -5.61 & 13.89 & -15.40 & 14.54 & -11.40 & 12.51 & -23.79 \\
\hline & Streamflow (cumec) & 1.08 & 7.06 & 0.95 & -5.86 & 1.16 & 15.51 & 0.98 & -2.88 \\
\hline B1 & $\mathrm{SCA}\left(\mathrm{km}^{2}\right)$ & 15.18 & -7.52 & 15.18 & -7.52 & 14.86 & -9.45 & 14.86 & -9.45 \\
\hline & Streamflow (cumec) & 0.93 & -7.65 & 0.99 & -1.69 & 1.04 & 3.58 & 0.99 & -1.59 \\
\hline $\mathrm{A} 2$ & $\mathrm{SCA}\left(\mathrm{km}^{2}\right)$ & 15.18 & -7.52 & 14.86 & -9.45 & 16.11 & -1.86 & 13.55 & -17.44 \\
\hline & Streamflow (cumec) & 0.91 & -9.34 & 1.01 & 0.40 & 1.20 & 19.68 & 1.00 & -0.70 \\
\hline IPCC & $\mathrm{SCA}\left(\mathrm{km}^{2}\right)$ & 15.80 & -3.73 & 15.80 & -3.73 & 16.41 & 0.00 & 17.02 & 3.68 \\
\hline & Streamflow (cumec) & 0.99 & -1.49 & 1.00 & -0.40 & 1.05 & 4.27 & 1.07 & 6.06 \\
\hline
\end{tabular}


scenarios (e.g., for B1 and IPCC commitment scenarios in 2040). Change in depletion pattern of the catchment under climate change has effect on time shifting of peak run-off in early spring month. From the comparative analysis of snow-covered area on a particular day (26th April), it is observed that in 2050, overall decrease in SCA varies from 10-24\% under A1B, A2 and B1 and corresponding streamflow decreases $0.7-3 \%$ from present climatic condition.

\section{References}

Abudu S, Cui C, Saydi M and King J P 2012 Application of snowmelt-runoff model (SRM) in mountainous watershed - A review; Water Sci. Engg. 5(2) 123-136.

Bandyopadhyay A, Bhadra A, Maza M and Shelina R K 2014 Monthly variations of air temperature lapse rates in Arunachal Himalaya; J. Indian Water Resour. Soc. 34(3) 16-25, ISSN: 0970-6984.

Bates B C, Kundzewicz Z W, Wu S and Palutikof J P (eds) 2008 Climate Change and Water; Technical Paper of the Intergovernmental Panel on Climate Change, IPCC Secretariat, Geneva, 210p.

Boudhar A, Hanich L, Boulet G, Duchemin B, Berjamy B and Chehbouni A 2009 Evaluation of the snowmelt runoff model in the Moroccan High Atlas Mountains using two snow-cover estimates; Hydrol. Sci. - Journal-des Sciences Hydrologiques 54(6) 1094-1113.

Collins W D, Bitz C M, Blackmon M L, Bonan G B, Bretherton C S, Carton J A, Chang P, Doney S C, Hack J J, Henderson T B, Kiehl J T, Large W G, McKenna D S, Santer B D and Smith R D 2006 The Community Climate System Model Version 3 (CCSM3); J. Climate $192122-2143$.

Dash S K, Jenamani R K, Kalsi S R and Panda S K 2007 Some evidence of climate change in twentieth-century India; Climate Change 85 299-321.

Gautam M R, Timilsina G R and Acharya K 2013 Climate Change in the Himalayas: Current State of Knowledge; Policy Research Working Paper 6516. The World Bank Development Research Group Environment and Energy Team.

Girod B, Wiek A, Mieg H and Hulme M 2009 The evolution of the IPCC's emissions scenarios; Environ. Sci. Policy, doi: 10.1016/j.envsci.2008.12.006.

Hall D K, Riggs G A, Salomonson V V, diGirolamo N E and Bayr K J 2002 MODIS snow-cover products; Remote Sens. Environ. 83 181-194.

Hong M A and Guodong C 2003 A test of Snowmelt-Runoff Model (SRM) for the Gongnaisi river basin in the western Tianshan Mountains, China; Chinese Sci. Bull. 48(20) 2253-2259.

Hughes D A, Hannart P and Watkins D 2003 Continuous baseflow separation from time series of daily and monthly streamflow data; Water SA 29(1) 43-48.

Jain S K, Kumar V and Saharia M 2012 Analysis of rainfall and temperature trends in northeast India; Int. J. Climatol., doi: 10.1002/joc.3483.
Kulkarani A V, Singh S K, Mathur P and Mishra V D 2006 Algorithm to monitor snow cover using AWiFS data of RESOURCESAT-1 for the Himalayan Region; Int. J. Remote Sens. 27(12) 2449-2457.

Kulkarni A V, Srinivasulu J, Manjul S S and Mathur P 2002 Field based spectral reflectance studies to develop NDSI method for snow cover monitoring; J. Indian Soc. Remote Sens. 30(1\&2) 73-80.

Ma Y, Huang Y, Chen X, Li Y and Bao A 2013 Modelling snowmelt runoff under climate change scenarios in an ungauged mountainous watershed, northwest China; Mathematical Problems in Engg., doi: $10.1155 / 2013 / 808565$.

Martinec J, Rango A and Roberts R 2008 Snowmelt-Runoff Model (SRM); User's Manual, WinSRM version 1.11 (eds) Gomez-Landesa E and Bleiweiss M P, New Mexico State University, Las Cruces, New Mexico, USA.

MOEF 2011 Project draft report on Arunachal Pradesh state action plan on climate change, 2011; Ministry of Environment and Forest (MOEF), Govt. of India, http:// envfor.nic.in/downloads/public-information/ArunachalPradesh-SAPCC.pdf.

Nakicenovic N and Swart R (eds) 2000 Special report: Emissions scenarios; Intergovernmental Panel on Climate Change (IPCC), Cambridge University Press, UK.

Nakicenovic N, Grubler A, Gaffin S, Jung T T, Kram T, Morita T, Pitcher H, Riahi K, Schlesinger M, Shukla P R, Vuuren D V, Davis G, Michaelis L, Swart R and Victor N 2003 IPCC SRES revisited: A response; Energy \&6 Environment 14(2\&3) 187-214.

PwC 2010 Third north east and east power summit: Profile and challenges - northeastern and eastern states of India; Energy and Utilities, Indian Chamber of Commerce (ICC), PricewaterhouseCoopers (PwC) Pvt. Ltd., India.

Rango A and Martinec J 1994 Areal extent of seasonal snow cover in a changed climate; Nordic Hydrology 25(4) $233-246$.

Senzeba K T, Bhadra A and Bandyopadhyay A 2015 Snowmelt runoff modelling in data scarce Nuranang catchment of eastern Himalayan region; Remote Sensing Applications: Society and Environment, pp. 20-35, ISSN: 2352-9385, doi: 10.1016/j.rsase.2015.06.001.

Solomon S, Qin D, Manning M, Chen Z, Marquis M, Averyt K B, Tignor M and Miller H L (eds) 2007 Climate change: The physical science basis; Contribution of working group I to the fourth assessment report of the Intergovernmental Panel on Climate Change (IPCC), Cambridge University Press, Cambridge, United Kingdom and New York, NY, USA.

Sorman A A, Gozel E and Sensoy A 2011 Snowmelt runoff prediction in the upper Euphrates basin, Turkey; In: Proc., 5th International Conference on Flood management (ICFM5) (27-29 September 2011), Tokyo, Japan.

Swain E, Stefanova L and Smith T 2014 Applying downscaled global climate model data to a hydrodynamic surface-water and groundwater model; Am. J. Clim. Change 3 33-49.

Welderufael W A and Woyessa Y E 2010 Streamflow analysis and comparison of base flow separion methods - Case study of the Modder river basin in central south Africa; European Water 31 3-12.

WMO 1964 Guide for Hydrometeorological Practices; World Meteorological Organisation (WMO), Geneva, Switzerland. 